Tjalling C. Koopmans Research Institute

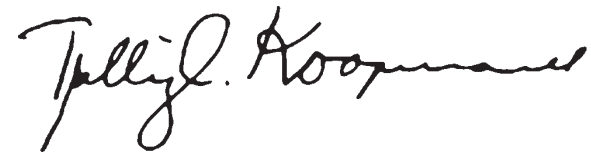

Discussion Paper Series nr: 07-31

\title{
GOODWILL, EXCESS RETURNS, AND DETERMINANTS OF VALUE CREATION AND OVERPAYMENT
}

Maaike Lycklama a Nijeholt Yolanda Grift 


\section{Tjalling C. Koopmans Research Institute Utrecht School of Economics \\ Utrecht University}

Janskerkhof 12

3512 BL Utrecht

The Netherlands

telephone $\quad+31302539800$

fax $\quad+31302537373$

website www.koopmansinstitute.uu.nl

The Tjalling C. Koopmans Institute is the research institute and research school of Utrecht School of Economics.

It was founded in 2003, and named after Professor Tjalling C. Koopmans, Dutch-born Nobel Prize laureate in economics of 1975.

In the discussion papers series the Koopmans Institute publishes results of ongoing research for early dissemination of research results, and to enhance discussion with colleagues.

Please send any comments and suggestions on the Koopmans institute, or this series to M.vanDort@econ.uu.nl

ontwerp voorblad: WRIK Utrecht

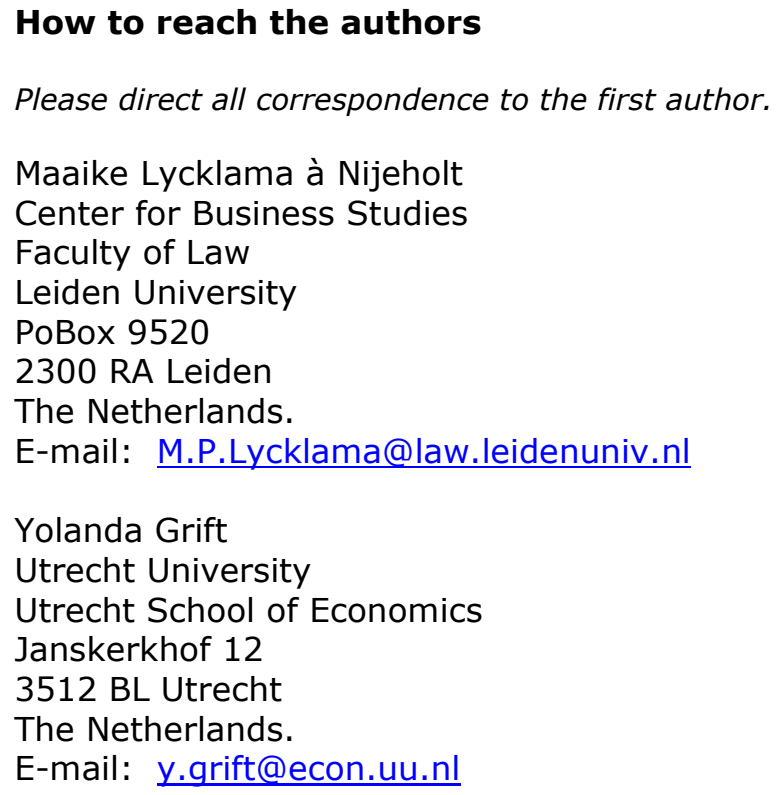


Utrecht School of Economics

Tjalling C. Koopmans Research Institute

Discussion Paper Series 07-31

\title{
GOODWILL, EXCESS RETURNS, AND DETERMINANTS OF VALUE CREATION AND OVERPAYMENT
}

\author{
Maaike Lycklama à Nijeholta \\ Yolanda Grift ${ }^{b}$ \\ ${ }^{a}$ Centre for Business Studies \\ Leiden University \\ bUtrecht School of Economics \\ Utrecht University
}

December 2007

\begin{abstract}
In this article we have investigated whether the determinants of excess returns (especially of target excess returns) are valid for purchased goodwill as well. Among them are acquirer's and target's Tobin's q, and debt assets ratio, that explain value creation of acquisitions, and relative size, source of financing of the acquisition, number of bidders, and relatedness of businesses of acquiror and target, that explain overpayment or overvaluation of acquisitions. The study is confined to mergers and acquisitions between US publicly quoted companies announced and effective in between January 2002 and December 2005. Databases used are SDC Platinum, CRSP and Compustat industrial annual file. Goodwill amounts are derived from acquirer's 10-K forms in Edgar database of SEC. Results show that in line with our expectations, the correlation coefficient for target excess return amounts and goodwill is positive, whereas it is negative for acquirer and combined excess returns. Further it turns out that goodwill is significant positively influenced by acquisitions of high Tobin's q targets by either low or high Tobin's q acquirers, compared to acquisitions of low Tobin's q targets by low Tobin's q acquirers. Also the method of payment matters: payments other than cash or stock negatively influence goodwill. Moreover, a higher leverage of the target positively influences purchased goodwill. Although some of the determinants of excess return have a significant influence on goodwill, the pattern is sometimes different. Therefore, further research needs to take into account both the nature of goodwill and its unique determinants.
\end{abstract}

Keywords: Goodwill, overpayment, value creation

JEL classification: G34, M41 


\section{INTRODUCTION}

Regarding regulations for accounting and reporting of purchased goodwill, some important changes have taken place. New regimes (IFRS (2005) as well as US GAAP (2001)) require (I) all mergers and acquisitions to be accounted for under the purchase method of accounting ${ }^{1}$, (II) any purchased goodwill to represent the purchase price of the acquired firm minus the fair value of its net assets, (III) identifiable intangible assets to be recorded separately, and (IV) amortisation of goodwill to be replaced by an annual impairment test. These new regulations result in larger availability of data of purchased goodwill and of further subdivision of the purchase price into other assets acquired and debt assumed in the annual reports of the acquiror. Furthermore, due to the more stringent regulation, the information content of purchased goodwill may have increased: it may have become a more concise term that contains relevant information about expected value creation or synergy of the acquisition, overvaluation or overpayment for the acquisition and going concern value of the target ${ }^{2}$. This study takes a leg up to examining the information content of purchased goodwill about the first two components: expected value creation and overvaluation or overpayment. First, this relationship will be examined by a simple correlation of the amounts of goodwill paid in acquisitions to the value of the abnormal rates of return on the stock of both acquirer and target around the announcement date of the acquisition. Then, we rely on earlier research in which acquirer's and target's Tobin's q, - size and - debt assets ratio, source of financing of the acquisition, number of bidders, attitude of the target toward the acquisition, and relatedness of businesses of acquirer and target were used to explain stock returns surrounding the takeover announcement. First we replicate the earlier studies by running regressions of acquirer-, target- and combined stock returns respectively on these explanatory variables. We then run a regression of goodwill on these explanatory variables. The study is confined to mergers and acquisitions between US publicly quoted

\footnotetext{
${ }^{1}$ The previously commonly used pooling of interests method in which no account was given about purchased goodwill is no longer permitted.

${ }^{2}$ Henning, Lewis \& Shaw (2000) decompose purchased goodwill into four components: (1) the write-up of the target firm's assets to their fair market value, (2) the extra value of the target as going concern, or standalone entity, (3) the synergistic value created by the acquisition, and (4) any overpayment or overvaluation for the target. New regulation has plausibly accentuated the information content of purchased goodwill, as the write-up component has been removed, and rules regarding identifiable intangible assets have become more stringent, resulting in less factors other than components (2) to (4) determining the value of purchased goodwill.
} 
companies announced and effective in between January 2002 and December 2005. Databases used are SDC Platinum, CRSP and Compustat industrial annual file. Goodwill amounts are derived from acquirer's 10-K forms in Edgar database of SEC.

Results show that in line with our expectations, the correlation coefficient for target excess return amounts and goodwill is positive, whereas it is negative for acquirer and combined excess returns. Further it turns out that goodwill is significant positively influenced by acquisitions of high Tobin's q targets by either low or high Tobin's q acquirers, compared to acquisitions of low Tobin's q targets by low Tobin's q acquirers. Also the method of payment matters: payments other than cash or stock negatively influence goodwill. Further, a higher leverage of the target positively influences purchased goodwill.

Section 2 expounds the theory on goodwill built up on the theory of excess returns. In section 3 , data and estimation model are described, followed by he results in section 4. Section 5 ends up with the conclusions.

\section{THEORY OF GOODWILL DETERMINANTS}

In literature, a number of explanations have been offered for acquirer and target stock returns around an acquisition announcement. Among them are acquirer's and target's Tobin's q, and debt assets ratio, that explain value creation of acquisitions, and relative size, source of financing of the acquisition, number of bidders, attitude of the target toward the acquisition, and relatedness of businesses of acquiror and target, that are explanations for overpayment or overvaluation of acquisitions. In this section, these determinants as well as their influence on excess returns are explained. Then, elaborating these explanations, we discuss/argue their expected influence on purchased goodwill.

\section{Tobin's q}

Lang, Stulz and Walkling (1989) use Tobin's q $\mathrm{q}^{3}$ as a measure of managerial performance of bidder and target in tender offers. They find that shareholders of high q bidders gain significantly more than shareholders of low q bidders and that shareholders of low q targets benefit more from takeovers than shareholders of high $\mathrm{q}$ targets. Their results suggest that high q bidders for low $\mathrm{q}$ targets undertake acquisitions with the largest total takeover gain. This indicates that considering the combination of Tobin's q's for acquirors and targets (into high high, low low, high low, and low low) might give more insight into the effect of the quality of management on value creation

\footnotetext{
${ }^{3}$ Tobin's q = firm's market value/firm's replacement value.
} 
of acquisitions. Servaes (1991) builds on the work of Lang, Stulz \& Walkling and shows that their findings also hold for mergers and after controlling for other determinants of takeover gains.

\section{Debt-assets ratio}

It is often stated that managers do not always behave in their investors best interests and therefore need to be disciplined (see for instance Harris \& Raviv (1990) and Jensen (1986)). Debt financing then serves as a disciplining device. The ability of the firm to make its contractual payments to debtholders provides information about managerial performance in the company. Therefore, the higher the debt ratio of the acquirer, the higher its stock returns. Besides, when the return on assets exceeds the required rate of return on debt, an increase of financial leverage increases stock returns of companies. Accordingly, it can be concluded that in those cases more debt financing of the acquirer further increases acquiror's stock returns. Same applies for the target's stock return: higher leverage leads to higher target returns.

\section{Relative size}

Regarding the effect of relative size of target and acquiror on acquiror stock returns, different explanations are available. With respect to bidder returns, Asquith, Bruner \& Mullins (1983) state that when two acquirors are experiencing the same dollar gain of an acquisition, the abnormal return to the larger acquiror will be lower. Another explanation is that in case of stock payments, a larger acquisition will imply a greater increase in the number of shares outstanding at completion of the acquisition, resulting in a decreasing abnormal return of the bidder with the relative size of the acquisition. Asquith, Bruner \& Mullins (1983) show a positive relative size ${ }^{4}$ coefficient, whereas Travlos (1987).shows a negative one. Moeller, Schlingemann \& Stulz (2004) relate the size-effect on acquiror stock returns to Roll's hubris hypothesis. They state that there are good reasons to think that managers of large firms are more prone to overconfidence, as "such managers might have made the firm large or, if not, they might have to overcome more obstacles to become CEOs than managers of small firms" (p 220). Those managers will overpay for the acquisition. We would like to bring up another argument, namely that the burden that has been imposed by the acquisition carries less weight with larger acquirors, resulting in an inclination of larger acquirors to overpayment. The expected effect of relative size on target stock returns is that the larger the acquirer is compared to the target, the higher the target returns, due to the tendency of overpayment of larger acquirors.

\footnotetext{
${ }^{4}$ In which relative size can be described as the size of the target divided by the size of the acquiror
} 


\section{Source of financing}

Travlos (1987) shows that the use of stock to finance takeovers causes negative acquiror returns: bidding firms suffer significant losses in pure stock exchange acquisitions, but they experience normal returns in cash offers. He concludes that in a world of asymmetric information, the method of payment may signal valuable information to the market. Managers will prefer a cash offer if they believe that their firm is undervalued and a stock exchange offer in the opposite case. Market participants interpret a cash offer as good news and a common stock exchange offer as bad news about the bidding firm's true value. Empirical studies by Franks, Harris and Meyer (1988) and Asquith, Bruner and Mullins (1990) show similar outcomes. With respect to target stock returns, two opposing hypotheses are available. Asquith, Bruner, and Mullins (1990) find evidence for the first hypothesis that stresses the tax effect of the method of payment of acquisitions. According to this theory, stock payments allow target shareholders to postpone capital gains taxes, whereas cash payments immediately impose capital gains taxes on target shareholders. Therefore, in case of cash payments, higher purchase prices are required, resulting in higher returns (before investor taxes) to the target. The opposing hypothesis, also mentioned by Asquith, Bruner \& Mullin (1990), suggests higher returns to targets in case of stock payments, as risk arbitrageurs, who specialize in the business of speculating on merger bids and don't experience any differential tax treatment on cash versus stock mergers, prefer cash payments to stock payments for reasons related to liquidity, transaction costs, and speed with which payment is received. Therefore, they prefer cash payments to stock payments and require higher target returns for stock financed mergers.

Further, it can be argued that cash payments discipline managers in the amount of payments, especially when these payments are debt financed. Especially stock swaps are less directly felt/experienced by bidders management, which may lead to a higher amount of payments, negatively influencing acquirors returns and positively influencing target returns.

\section{Number of bidders}

Acquirer and target stock returns are also related to the number of bidders. More than one bidder competing for the target increases the purchase price of the target, resulting in a lower ultimate stock return of the bidder, and a higher stock return of the target.

\section{Relatedness of businesses}

Morck, Shleifer \& Vishny (1990) argue why managers would pursue unrelated diversification even when it hurts shareholders: first, to reduce the risk of their human capital; second, to assure 
the survival and continuity of the firm, and third, when poor performance of the firm threatens their jobs, they have an incentive to enter new businesses at which they might be better. In all these cases, managers might be willing to overpay for targets outside the bidding firm's industry, reducing the wealth of their shareholders.

\section{Influences of determinants on goodwill}

We expect the discussed determinants for stock returns to explain the amount of purchased goodwill as well. To be more precise, we expect the influence of these determinants on purchased goodwill to be comparable to their influence on target stock returns: target stock returns resemble target shareholders expectations about their returns from the acquisition. Their expectations are determined by expected value creation of the acquisition and its expected overvaluation or overpayment. These are also two of the three elements purchased goodwill consists of ${ }^{5}$. However, there's a big difference between target stock returns and purchased goodwill: whereas target stock returns surrounding the acquisition announcement correspond to shareholders expectations of stock returns from the acquisition, purchased goodwill refers to a realized amount of money. This difference makes goodwill a research worthy alternative of target stock return.

Table 1 summarizes the expected interrelationship between determinants on the one hand, and stock returns, and purchased goodwill on the other, as derived from literature.

\footnotetext{
${ }^{5}$ The third element goodwill consists of is the extra value of the target company due to its uprating from fair value to going concern value.
} 
Table 1: interrelationship determinants, excess returns, and goodwill in acquisitions

\begin{tabular}{|l|l|l|l|l|}
\hline Determinants & $\begin{array}{l}\text { Acquiror's } \\
\text { excess } \\
\text { return }\end{array}$ & $\begin{array}{l}\text { Target's } \\
\text { excess } \\
\text { return }\end{array}$ & $\begin{array}{l}\text { Excess return } \\
\text { combination }\end{array}$ & Goodwill \\
\hline Tobin's q acquirer & positive & positive & positive & Positive \\
\hline Tobin's q target & negative & negative & negative & Negative \\
\hline Acquirer's debt/assets ratio & positive & positive & positive & Positive \\
\hline Target's debt/assets ratio & positive & positive & positive & Positive \\
\hline $\begin{array}{l}\text { Relative size target- } \\
\text { acquirer }\end{array}$ & $\begin{array}{l}\text { Positive or } \\
\text { negative }\end{array}$ & negative & unknown & Positive \\
\hline Source of financing: cash & positive & $\begin{array}{l}\text { positive or } \\
\text { negative }\end{array}$ & unknown & $\begin{array}{l}\text { positive or } \\
\text { negative }\end{array}$ \\
\hline Number of bidders & negative & positive & unknown & Positive \\
\hline Target's attitude: hostile & negative & positive & unknown & Positive \\
\hline $\begin{array}{l}\text { Relatedness of } \\
\text { Businesses: unrelated }\end{array}$ & negative & positive & unknown & Positive \\
\hline
\end{tabular}

\section{DATA AND ESTIMATION MODEL}

\section{DATASOURCE}

The initial sample of acquisitions is compiled from the Securities Data Company's (Platinum SDC) database. Mergers and acquisitions selected are between US publicly quoted companies with announcement dates as well as effective dates between January 2002 and December 2005. Only acquisitions in which acquiring firms end up with $100 \%$ of the shares of the acquired firm are considered, and the acquiring firm is required to control no shares of the target firm before the announcement. Further it is required that the form of the deal is an acquisition, an acquisition of assets, or a merger. Mergers and acquisitions in which acquiror, target or both are financial companies (1-digit SIC code 6) are excluded.

Purchased goodwill data have been derived from acquirers 10-K form annual reports with SEC's filings and forms (EDGAR). Excess stock returns of acquirers and targets were measured making use of data available in CRSP. Acquirer as well as the target must be listed on the Center for Research in Security Prices (CRSP) for 205 days before the announcement date and 10 
days after it. Explanatory variables have been derived from data available in Compustat North America database and Platinum SDC database. Compustat North America database information must be available of both acquiror and target up to 3 fiscal years preceding the fiscal year in which the acquisition has been realized

The Platinum-SDC database provides 399 mergers and acquisitions between non financial US publicly quoted companies, 205 of which fulfil all requirements. Adjusting for outliers and combinations of characteristics ${ }^{6}$, the dataset used consists of 203 observations for analyses with excess returns and of 153 observations for analyses with goodwill.

\section{$\underline{D A T A}$}

Table 2 presents the descriptives of the variables used in the analyses. We start with a description of dependent variables, and then briefly describe the explanatory variables.

Following Brown and Warner (1985), the calculation of excess returns is conducted according to the OLS market model. The parameters for the OLS market model are estimated over the (-205, 6) interval, using the CRSP equally weighted market index returns. The event window used to calculate the cumulative excess returns is a five day time period: $(-2,+2)$. Combined excess returns of acquiror and target are calculated by multiplying their excess returns with their marketcapitalization 3 days before the announcement day and dividing this amount by their total marketcapitalization 3 days before the announcement day.

It turns out that acquiror's shareholders are harmed by the acquisition: they lose value due to stock price decreases: their average excess return amounts to $-1,70 \%$. The negative return to acquiror's shareholders indicates that on average acquiror's overpay for an acquisition. Yet, target's stock returns are highly positive: $22,14 \%$. The slightly positive cumulative excess return of the combination of acquiror and target of $0,93 \%$ indicates that on average acquisitions are expected to create value.

The average amount of purchased goodwill adds to $\$ 858.067 .000$, with a large variation from $\$ 494.000$ to $\$ 34.943 .000 .000$. The relative goodwill, in which goodwill is divided by its transaction value to correct for the size of the acquisition, is on average $57,47 \%$ and varies from $1,77 \%$ to $169,55 \%$.

\footnotetext{
${ }^{6}$ In the Compustat North America database, on individual level sometimes only limited information is available: some financial data are missing.
} 
Following Chung \& Prutt, Tobin's $q$ is calculated as market value of the assets divided by their book value. A high Tobin's q is an indication of good performance of management of the company. Mean acquiror's Tobin's q is 2,13, and target's Tobin's q is 1,91.

Dividing companies into high Tobin's q and low Tobin's q, based on median values, we find that of the acquisitions one third are between low Tobin's q acquirers and low Tobin's q targets, one third between high Tobin's q acquirers and high Tobin's q targets, and one third between high Tobin's q acquirors and low Tobin's q targets or vice versa.

It further turns out that in only $5 \%$ of the acquisitions, more than one bidder was involved.

On average, payments for acquisitions consist for $53 \%$ of cash, $42 \%$ of stock, and $5 \%$ of other securities. About $39 \%$ of the acquisitions are fully paid for in cash.

Relative size is calculated as the fraction of the target market capitalization of the acquiror market capitalization three days before the announcement date. On average, acquirors are about 4 times larger in size than the targets.

Debt assets ratio is based on market value (following Moeller e.a. (2004)). It turns out that about $30,1 \%$ of targets assets and $25,3 \%$ of acquirors assets are financed with debt.

Almost half of the acquisitions are between companies in the same industry, based on the four digit SIC code.

table 2: data descriptives

\begin{tabular}{|c|c|c|c|c|c|c|}
\hline Variable & $\mathrm{N}$ & Freq. & Mean & Std.Dev. & Min & Max \\
\hline \multicolumn{7}{|l|}{ Dependent variables } \\
\hline Acquirer excess return & 203 & & -.017 & .086 & -0.383 & .291 \\
\hline Target excess return & 203 & & .221 & .306 & -.344 & 2.377 \\
\hline Combined excess return & 203 & & .009 & .080 & -.249 & 285 \\
\hline Goodwill & 153 & & 858.067 & 3349.839 & .494 & 34943 \\
\hline Relative goodwill & 153 & & .575 & .377 & .018 & 3.56 \\
\hline \multicolumn{7}{|l|}{ Explanatory variables } \\
\hline Acquirer Tobin's q & 203 & & 2.134 & 1.174 & .611 & 7.275 \\
\hline Target Tobin's q & 203 & & 1.914 & 1.185 & 297 & 7.207 \\
\hline $\begin{array}{cc}\text { Acquirer - target: } \\
\text { - } \quad \text { Low - low } \\
\text { - low - high } \\
\text { - high - low } \\
\text { - high - high }\end{array}$ & 203 & $\begin{array}{l}68 \\
32 \\
33 \\
70\end{array}$ & & & & \\
\hline $\begin{array}{c}\text { Number of bidders } \\
-1 \\
-1 \\
\cdot \quad 3 \\
\end{array}$ & 203 & $\begin{array}{l}193 \\
7 \\
3\end{array}$ & 1.064 & .300 & 1 & 3 \\
\hline $\begin{array}{l}\text { Source of financing } \\
\text { - } \text { cash } \\
\text { - } \\
\text { - } \\
\text { stocks } \\
\text { other securities }\end{array}$ & 203 & & $\begin{array}{r}52.637 \\
5.019 \\
42.344\end{array}$ & $\begin{array}{l}44.766 \\
12.522 \\
44.071\end{array}$ & $\begin{array}{l}0 \\
0 \\
0\end{array}$ & $\begin{array}{r}100.00 \\
66.67 \\
100.00\end{array}$ \\
\hline
\end{tabular}




\begin{tabular}{|c|c|c|c|c|c|c|}
\hline $\begin{array}{l}\text { Source of financing } \\
\qquad \quad \text { less than } 100 \% \text { cash } \\
-\quad 100 \% \text { cash }\end{array}$ & 203 & $\begin{array}{l}124 \\
79\end{array}$ & .389 & & & \\
\hline Relative size & 203 & & .275 & .361 & .000 & 2.533 \\
\hline Acquiror debt-assets ratio & 203 & & .253 & .162 & .006 & .759 \\
\hline Target debt-assets ratio & 203 & & .303 & .217 & .018 & .926 \\
\hline $\begin{array}{l}\text { Same sector (4 digit SIC-code) } \\
-\quad \text { no } \\
-\quad \text { yes }\end{array}$ & 203 & $\begin{array}{l}109 \\
94\end{array}$ & .463 & & & \\
\hline
\end{tabular}

\section{ESTIMATION MODEL}

Next to a closer look at the correlations between goodwill and excess return amounts, we will perform a multivariate analysis. We first replicate the earlier studies by running a multivariate regression of acquirer-, target- and combined excess returns respectively on the explanatory variables mentioned above. To gain insight into the information content of goodwill about value creation and overpayment, we then regress goodwill on the same explanatory variables. This leads to the following regression equations for acquirer-, target- and combined excess returns:

$$
\begin{aligned}
\text { Car }= & \beta_{0}+\beta_{1} \text { alow_thigh_Tobins_ } q+\beta_{2} \text { ahigh_tlow_Tobins_ } q+\beta_{3} \text { ahigh_thigh_Tobins_q }+ \\
& \beta_{4} \text { Number_of_Bidders }+\beta_{5} \%{ }_{-} \text {Cash }+\beta_{6} \%{ }_{-} \text {Other }+\beta_{7} \ln (\text { relativesize })+ \\
& \beta_{8} a \_ \text {Debt_to_assets_ratio }+\beta_{9} t_{-} \text {Debt_to_assets_ratio }+\beta_{10} \text { Same_industry }+\varepsilon
\end{aligned}
$$

and for goodwill:

$$
\begin{aligned}
\text { Goodwill/Value_of_transaction } & =\beta_{0}+ \\
& \beta_{1} \text { alow_thigh_Tobins_q }+\beta_{2} \text { ahigh_tlow_Tobins_ } q+\beta_{3} \text { ahigh_thigh_Tobins_q+ } \\
& \beta_{4} \text { Number_of_Bidders }+\beta_{5} \%{ }_{-} \text {Cash }+\beta_{6} \%_{-} \text {Other }+\beta_{7} \ln (\text { relativesize })+ \\
& \beta_{8} a_{-} \text {Debt_to_assets_ratio }+\beta_{9} t_{-} \text {Debt_to_assets_ratio }+\beta_{10} \text { Same_industry }+\varepsilon
\end{aligned}
$$

\section{RESULTS}

In this section, we start with a correlation of goodwill and excess return amounts. Table 3 shows the correlation coefficients. All coefficients are significant (p-value=0,00). In line with our expectations, the correlation coefficient for target excess return amounts and goodwill is positive, whereas it is negative for the other two correlations. Both target excess return amounts and goodwill are indicators of overvaluation and value creation of the acquisition. Apparently, target shareholders expectations about overpayment and value creation of the acquisition are met by the amount of purchased goodwill. Also, acquiror shareholders expectations about overpayment for 
the acquisition seem to be met by the amount of purchased goodwill: the lower their excess return, the higher the amount of purchased goodwill. The negative correlation coefficient of goodwill and excess return amount of the combination might be an indication for empire building and hubris of acquirer's management.

Table 3: correlation coefficients excess return amounts and goodwill

\begin{tabular}{|l|c|}
\hline $\begin{array}{l}\text { Cumulative excess return amounts } \\
\text { Event period }-2,+2\end{array}$ & Goodwill \\
\hline Acquirer excess return amount & $-0.667^{*}$ \\
\hline Target excess return amount & 0.815 \\
\hline Combined excess return amount & -0.521 \\
\hline
\end{tabular}

Table 4 shows the results of the multivariate analyses explaining both excess returns and goodwill. Results will be discussed for each explanatory variable.

Conform theory, an acquisition of a low Tobin's q target by a high Tobin's q acquirer ("a high t low") has a significant positive effect on target excess returns, compared to an "a low $\mathrm{t}$ low" acquisition. Further, compared to an "a low t low" acquisition, an "a low $\mathrm{t}$ high" acquisition significantly increases the excess returns of acquirer, the excess returns of the combination, and goodwill. Goodwill is significantly positively influenced by a "high a high t" acquisition, when compared to a "low a low t" target. No significant effects were found for an "a high $\mathrm{t}$ low" acquisition when compared to an "a low t low" acquisition. Strikingly, an "a high t low" acquisition doesn't generate the highest excess returns to acquirer and combination, as found by Lang, Stulz, and Walkling (1989).

As expected, a higher number of bidders significantly negatively influences the acquiror excess return. Surprisingly, the number of bidders doesn't influence goodwill. This might be due to the data availability (only in 5\% of the acquisitions more bidders were involved).

There is a significantly positive influence of the percentage of cash in payments on acquirer excess returns. Also the percentage of sources of financing other than cash and equity positively influences acquirer excess returns. This is in line with the theory that managers will prefer a cash offer if they believe that their firm is undervalued and a stock exchange offer in the opposite case. 
Not surprisingly, the same theory seems to hold for sources of financing other than cash and equity. Same effects apply for the excess returns of the combination.

Apparently, there is no effect of percentage of cash in payments on target excess returns. This is an indication that none of the two opposing theories of target stock return reaction on cash payment is dominant over the other. So more information is needed to separate these theories. Same results apply for their effect on goodwill, although for goodwill also the percentage of sources of financing other than cash and equity negatively influences purchased goodwill. It could be that these sources of financing are relatively cheap (for instance payment in options), resulting in a lower purchase price and lower goodwill.

As expected, relative size has a significant negative influence on target excess returns. We don't find this effect on purchased goodwill. Relative size also doesn't influence the acquirer excess returns. Again, there's inconclusive evidence two support one of the two theories about the influence of relative size on acquirer excess returns.

Conform theory, target excess returns and goodwill are significant positively influenced by a higher target debt asset ratio.

Effects of relatedness of businesses on target excess returns are significant and positive. This is not in accordance with the empire building theory of Morck, Shleifer \& Vishny (1990). On the other hand, it might indicate that acquisitions in the same industry are more value creating, resulting in a higher target excess return.

Table 4: regression results explaining both excess return and goodwill

\begin{tabular}{|c|c|c|c|c|}
\hline & \multicolumn{4}{|c|}{$\begin{array}{l}\text { Regression coefficients } \\
\text { (t-statistics) }\end{array}$} \\
\hline & $\begin{array}{l}\text { Target excess } \\
\text { return }\end{array}$ & $\begin{array}{l}\text { Acquirer excess } \\
\text { return }\end{array}$ & $\begin{array}{l}\text { Combined } \\
\text { excess return }\end{array}$ & $\begin{array}{l}\text { Relative } \\
\text { goodwill }\end{array}$ \\
\hline \multirow[t]{2}{*}{$\begin{array}{l}\text { Tobin's q: } \\
\text { Acquirer low - target high }\end{array}$} & 0.062 & $0.039 * *$ & $0.043 * *$ & $0.133^{*}$ \\
\hline & $(0.98)$ & $(2.16)$ & $(2.52)$ & $(1.84)$ \\
\hline \multirow[t]{2}{*}{ Acquirer high - target low } & $0.148 * *$ & -0.001 & 0.009 & 0.075 \\
\hline & $(2.18)$ & $(0.03)$ & $(0.47)$ & $(0.89)$ \\
\hline \multirow[t]{2}{*}{ Acquirer high - target high } & 0.019 & -0.001 & 0.001 & $0.151 * *$ \\
\hline & $(0.31)$ & $(0.09)$ & $(0.07)$ & $(2.11)$ \\
\hline Number of bidders & -0.048 & $-0.032 *$ & -0.023 & -0.043 \\
\hline
\end{tabular}




\begin{tabular}{|c|c|c|c|c|}
\hline & $(0.72)$ & $(1.69)$ & $(1.28)$ & $(0.55)$ \\
\hline Percentage of stock payment & - & - & - & - \\
\hline \multirow[t]{2}{*}{ Percentage of cash payment } & 0.000 & $0.001 * * *$ & $0.001 * * *$ & -0.000 \\
\hline & $(0.64)$ & $(4.47)$ & $(3.95)$ & $(0.18)$ \\
\hline \multirow[t]{2}{*}{ Percentage of other payment } & -0.000 & $0.001 * *$ & $0.001 * *$ & $-0.006 * * *$ \\
\hline & $(0.09)$ & $(2.52)$ & $(1.99)$ & $(2.94)$ \\
\hline \multirow[t]{2}{*}{ Relative size $(\ln )$} & $-0.059 * * *$ & -0.004 & 0.004 & 0.017 \\
\hline & $(4.04)$ & $(0.87)$ & $(0.95)$ & $(0.83)$ \\
\hline \multirow[t]{2}{*}{ Target debt to assets ratio } & $0.227^{*}$ & 0.050 & $0.055^{*}$ & $0.420 * * *$ \\
\hline & $(1.97)$ & $(1.52)$ & $(1.77)$ & $(3.00)$ \\
\hline \multirow[t]{2}{*}{ Acquirer debt to assets ratio } & -0.185 & 0.021 & -0.001 & -0.039 \\
\hline & $(1.20)$ & $(0.47)$ & $(0.02)$ & $(0.21)$ \\
\hline \multirow[t]{2}{*}{ Same industry (4 digit) } & $0.074 *$ & -0.008 & -0.000 & -0.024 \\
\hline & $(1.82)$ & $(0.71)$ & $(0.01)$ & $(0.49)$ \\
\hline \multirow[t]{2}{*}{ Constant } & 0.026 & $-0.054 *$ & -0.017 & $0.498 * * *$ \\
\hline & $(0.26)$ & $(1.90)$ & $(0.62)$ & $(4.32)$ \\
\hline Number of observations & 203 & 203 & 203 & 153 \\
\hline R-squared & 0.22 & 0.22 & 0.16 & 0.10 \\
\hline $\mathrm{F}$ & 5.37 & 5.32 & 3.68 & 1.66 \\
\hline Prob $>F$ & 0.0000 & 0.0000 & 0.0002 & 0.0963 \\
\hline R2 adj & 0.1779 & 0.1762 & 0.1171 & 0.0415 \\
\hline
\end{tabular}

\section{CONCLUSIONS}

In this article we have investigated whether the determinants of excess returns (especially of target excess returns) are valid for purchased goodwill as well. Among them are acquirer's and target's Tobin's q, and debt assets ratio, that explain value creation of acquisitions, and relative size, source of financing of the acquisition, number of bidders, and relatedness of businesses of acquiror and target, that explain overpayment or overvaluation of acquisitions.

The correlation coefficient for target excess return amounts and goodwill is strongly positive, which indicates that shareholders expectation about value creation and overpayment to a large extent are met by the amount of purchased goodwill. Also, acquiror shareholders expectations about overpayment for the acquisition seem to be met by the amount of purchased goodwill: the lower their excess return, the higher the amount of purchased goodwill. The negative correlation coefficient of goodwill and excess return amount of the combination might be an indication for empire building and hubris of acquirer's management.

It turns out that goodwill is significant positively influenced by acquisitions of high Tobin's q targets by either low or high Tobin's q acquirers, compared to acquisitions of low Tobin's q targets by low Tobin's q acquirers. Also the method of payment matters: payments other than cash or stock negatively influence goodwill. A higher leverage of the target positively influences purchased goodwill. 
Although some of the determinants of excess return have a significant influence on goodwill, the pattern is sometimes different. Therefore, further research needs to take into account both the nature of goodwill and its unique determinants. With respect to the nature of goodwill, besides value creation and overpayment, its going concern component needs to be taken into account. Regarding the unique determinants of goodwill, we will extent our analysis to other intangibles, sector specific information on goodwill, and impairment. 


\section{REFERENCES}

Asquith, P., R.F. Bruner \& D.W. Mullins (1983), The gains to bidding firms from merger, Journal of Financial Economics 11 (1983) 121-139*

Asquith, P., Bruner, R. and Mullins, D. jr. (1990), Merger returns and the form of financing, working paper, Harvard University

Brown, S.J.\& J.B.Warner (1985), Using daily stock returns: the case of event studies, Journal of Financial Economics 14 (1985) 3-31.

Chung K.H. and S.W. Prutt, A simple approximation of Tobin's q, Financial Management, Vol 23, No. 3, 1994, p 70-74

Franks, J.R., R.S. Harris and C.Mayer (1988), Means of payment in takeovers: results for the UK and USA, in Auerbach, A.J.ed. Corporate takeovers: causes and consequences, National Bureau of Economic Research

Harris M. \& A. Raviv (1990), Capital structure and the information role of debt, The Journal of Finance, Vol. 45, No. 2, p 321-349

Henning S.L., B.L.Lewis \& W.H.Shaw Valuation of the Components of

Purchased Goodwill, Journal of Accounting Research, Vol 38, No. 2, Autumn 2000

Jensen, M.C. and R.S. Ruback (1983), The market for corporate control: the scientific evidence, Journal of Financial Economics, 11, 5-50

Jensen, M.C.(1986), Agency costs of free cash flow, corporate finance, takeovers, American Economic Review, p 323-329

Lang, L.H.P., Stulz, R.M. and R.A. Walkling (1989), Managerial performance, Tobin,s q, and the gains from successful tender offers, Journal of Financial Economics, 24, 137-154

Lang, L.H.P., Stulz, R.M. and R.A. Walkling (1991), A test of the free cash flow hypothesis: the case of bidder returns, Journal of Financial Economics, 29, 315-335

Martin, K.J. (1996), The method of payment in corporate acquisitions, investment opportunities, and management ownership, The Journal of Finance, LI (4), 1227-

Matsusaka, J.G. (1993), Target profits and managerial discipline during the conglomerate merger wave, The Journal of Industrial Economics, XLI (2), 179-189

Moeller, S.B., F.P. Schlingemann \& R.M. Stulz (2004), Firm size and the gains from acquisitions, Journal of Financial Economics 73 (2004) 201-228

Morck, R., Schleifer, A. and R.W. Vishny (1990), Do managerial objectives drive bad acquisitions?, The Journal of Finance, XLV (1), 31-48

Roll, R. (1986), the Hubris hypothesis of corporate takeovers, The Journal of Business, Vol. 59, No.2, part 1, p 197-216

Servaes, H.(1991), Tobin's q and the gains from takeovers, The Journal of Finance, LXVI (1), 409-419

Travlos (1987), N.G., Corporate takeover bids, methods of payment, and bidding firms stock returns, The Journal of Finance, Vol. 42, No. 4, p 943-963

Vander Vennet, R., (1996), The effect of mergers and acquisitions on the efficiency and profitability of EC credit institutions, Journal of Banking and Finance, 20, 1531-1558 